\title{
Unpacking the Financial Services and Crowdfunding Evolution in the Sharing Economy
}

\section{Agnieszka Lukasiewicz and Mijalche Santa}

\section{Theoretical Background}

As a start, it would be essential to have here some basics for contextualisation: why financial services are interesting areas for the sharing economy. Providing an alternative in the financial sector sharing economy presents many benefits - what are those? And why is it important? How does it disrupt the established systems of financial service provisions? Is there any sustainability ambitions in creating such alternative? How are sustainable finances redefined by those services? Do they integrate in some way or

\author{
A. Lukasiewicz $(\bowtie)$ \\ Management Systems and Telematics Division, Road and Bridge \\ Research Institute, Warsaw, Poland \\ e-mail: alukas@ibdim.edu.pl \\ M. Santa \\ Faculty of Economics-Skopje, Ss. Cyril and Methodius \\ University, Skopje, North Macedonia \\ e-mail:mijalche.santa@eccf.ukim.edu.mk
}


the other environmental, social, and governance (ESG) criteria? Which areas are the most penetrated by the new providers or look exciting for academic research with regard to financial service provisioning (such as leasing, hedging, insurance. banking)?

The financial crisis of 2008-2009 was a trigger for strengthening the proliferation of alternative forms of financing. At the same time, banks that hold more capital reduced lending, particularly in the small and medium enterprises sector, a need and gap in funding, especially those entities raised. Crowdfunding may be classified into four categories: social lending/donation crowdfunding, reward crowdfunding, peer-topeer lending, and equity crowdfunding (Pierrakis and Collins 2013). Especially peer-to-peer lending and equity crowdfunding are growing rapidly and are easily accessible to both retail and sophisticated investors alike (Kirby and Worner 2014). Those crowdfunding forms have also drawn the attention of governments and the European Commission, who would wish to encourage the growth of SMEs. Crowdfunding is also referred to as sustainability by integrating with a triple bottom line approach, which embraces economic, environmental, and societal issues (Elkington 1999). It also indicates sustainable entrepreneurs regard a wide range of various stakeholder interests (Bocken 2015).

The most popular form of alternative financing-crowdfunding is expanding in different sectors filling the gap of funding, especially on the micro and small enterprises level. In the literature one finds different definitions of crowdfunding (Berns et al. 2020; Rossi and Vismara 2018; Short et al. 2017; Renwick and Mossialos 2017; Schwienbacher and Larralde 2012). Nevertheless, 'crowd' indicates the process needs contribution from many participants. The European Commission defines crowdfunding as an emerging source of financing involving open calls to the public, generally via the Internet, to finance projects through monetary contributions in exchange for a reward, product preordering, lending, or investment (European Commission 2020a). For small businesses, access to this form of finance represents an alternative (or a complement) to more traditional sources of finance, such as debt finance. Crowdfunding platforms are websites where fundraisers such as small and medium enterprises can source financial pledges from a crowd (European Commission 2020a). Crowdfunding is also defined as an 
alternative channel for financing a project that uses an online platform to solicit generally small contributions from numerous participants (i.e. the crowd) (Renwick and Mossialos 2017). In a wide way, crowdfunding is defined as the financing of a project or a venture by a group of individuals instead of professional parties (e.g. banks, venture capitalists, or business angels), and the typical mode of communication is through the Internet (Schwienbacher and Larralde 2012). The phenomenon of crowdfunding brings out insight from micro-finance (Morduch 1999) and crowdsourcing (Poetz and Schreier 2012) concepts. However, it represents its own kind of fundraising, assisted by an increasing number of internet sites assigned to the issue. It is related mainly to small companies, micro-businesses, and individual entrepreneurs to find financial resources in an internet-dominated world. While entrepreneurs have an idea, it is not obligatory to prepare complex materials to apply for bank loans or government subsidies through complicated procedures (Zhao et al. 2017). What is needed to address funding using such platforms as Kickstarter and Indiegogo is to post general information, e.g. amount of requested capital, types of rewards, as well as make a presentation of a project.

According to (Belleflamme et al. 2014) there are three characteristics of crowdfunding:

- Crowdfunding initiatives rely on the advanced purchase of products that are not available on the market. Entrepreneurs who start crowdfunding projects describe what the final products are and offer a list of monetary or non-monetary rewards for sponsors who are willing to invest (cf. future markets).

- Consumers or sponsors pay more in the pre-ordering process than do traditional consumers, who wait to buy the finished products on the market (cf. spot markets).

- Crowdfunders identify themselves as members of the community. Such community can shape from receiving rewards up to being involved in the project. Entrepreneurs ensure the consumers value the community, benefits, as well as trust in the project. 
Except for the social network theory, crowdfunding is often connected to a theory of 'warm-glow giving' (Andreoni 1990). The literature on altruism and the theory notes some individuals feel positive when helping others. Moreover, the theory could explain a backer's decision to participate in a crowdfunding campaign for a social impact project. The theory also leads to funders perceiving they are part of a civic project (Lagazio and Querci 2018). Furthermore, as stated by a resource-based theory, resources are the primary source of company performance and direct a firm's strategy (Grant 1991). In crowdfunding models and practices can be found the optimisation of both financial, as well as human resources. Furthermore, an entrepreneurial team is recognised as a positive one in those determinants of a firm's growth (Ensley et al. 2002; Ruef et al. 2003). It also can benefit from a wider network of contacts. Undoubtedly, internet technologies, social media, and various platforms have been a trigger to the development of networks. The networks which are becoming bigger, with no boundaries, are used in crowdfunding to the improvement in using financial and human sources. Also, the continuity of technology growth is followed by the FinTech (Financial Technology - the term refers to software and other new technologies used by businesses that provide automated and improve financial services) industry expansion. Thus, the power of crowd and technology is used in the funding/financing activity in the range of various creative initiatives.

\section{Financial Services Models in the Sharing Economy}

There are two approaches to categorising the crowdfunding models. The most widespread is the one that is based on what the crowdfunders receive in exchange for their contributions. Based on it, we have donation-based, reward-based, equity-based, royalty-based, and lendingbased financial services. Other taxonomies are based on the timing of the campaign. Money collection scheme and presence or absence of intermediary (Butticè et al. 2018). In this section, we will present an overview of the most dominant taxonomy. 


\section{Donation-Based Platforms}

The donation-based platforms request monetary and/or non-monetary resources without expecting to receive any material rewards (SalidoAndres et al. 2021). Donation-based crowdfunding is a niche crowdfunding focused on public goods (Guan 2016). They cover topics 'from rescuing homeless animals to overcoming medical crises, eliminating community problems to reallocating educational resources' (Wang et al. 2019, p. 1517). One example of this type of platform is GoFundMe. As online philanthropy innovation, this type of crowdfunding gains more and more popularity (Zhang et al. 2020). They provide an additional revenue stream for charitable organisations. The full potential of this type of crowdfunding is most evident during the COVID-19 pandemic, as we will present in the next sections.

\section{Reward-Based Funding}

In reward-based crowdfunding, creators will provide tangible rewards to supporters (Guan 2016). The creators are typically individuals (Rossi and Vismara 2018) with an innovative idea for which they need financial support. To receive the financial support creators, explain their idea, the project through which they will instantiate their idea and the rewards they will provide to supporters if the funding goal is achieved (Herrero et al. 2020). Kickstarter is one of the largest rewards-based crowdfunding platforms. In some of the reward crowdfunding, supporters select to invest based on their interests to get certain perks such as advance versions of a funded product (Short et al. 2017). However, sometimes the reward can be merely symbolic, such as thank you note, and in these cases, the difference between donor and reward crowdfunding is not clear (Butticè et al. 2018). In reward-based funding, the goal is to try to raise as much as possible funds (Rossi and Vismara 2018). This is not the case for equity-based crowdfunding. 


\section{Equity-Based Platforms}

In equity-based crowdfunding, the proponent is a company that sells small ownership stakes in their firms (Mochkabadi and Volkmann 2020). The proponent offers a maximum number of shares that can be sold in order to not dilute equity ownership (Rossi and Vismara 2018). The benefit for the supporters is that through their investment, they will be eligible to receive a share of the profits in the form of a dividend to distribution (Wang et al. 2019). A representative example of this type of platform is the WeFunder platform. The benefit for the creators is that it can be an alternative financial investment instrument (Cai 2018) through which it can obtain not only funds in the earlystage projects (Martínez-Climent et al. 2018) but also receive feedback from the crowd on their entrepreneurial endeavour (Butticè et al. 2018). Thus, this is not only an innovative way to raise external capital for new ventures (Mochkabadi and Volkmann 2020) but also to engage in communication with potential customers. The platforms play a critical role in this communication in which they transition from active intermediaries that critically assess ventures to providers of lean business introduction services that assist ventures in reducing their information asymmetries with the crowd' (Löher 2017, p. 19). This is an important role because equity crowdfunding provides investment opportunities for small investors who lack the sense, knowledge, or capabilities of researching for investments (Martínez-Climent et al. 2018).

\section{Lending-Based Platforms}

Peer-to-peer-lending crowdfunding involves investors making microloans to entrepreneurs (Short et al. 2017) by bypassing traditional banks (Belleflamme et al. 2015). The loans are returned over a pre-determined timeline (Wang et al. 2019) with interest, or only the principal is returned (Allison et al. 2013). The interest rate is flexible and can be determined by an algorithm (Butticè et al. 2018). Zopa in the UK is an example of this type of platform. Research demonstrates that the lenders 
in lending-based crowdfunding tend to follow strategic over altruistic motives (Berns et al. 2020).

In the next section, we present the value of all these different crowdfunding models.

\section{The Value Market of Alternative Financing}

Depending on the source of information, as well as the scope of the definition of crowdfunding, the crowdfunding market in 2018 was valued at USD 10.2 billion reported by Valuates Reports (2019b), trough up to USD 357 billion reported by the Cambridge Centre for Alternative Finance (CCAF) (Ziegler and Shneor 2020). It is important that the phenomenon affects all continents and a very large number of countries. Crowdfunding platforms are developing both in Asia-with the Chinese market dominating and the largest in the world, and in Africa, although, in relation to the level of economic development, the value of crowdfunding on that continent is the lowest in terms of value.

Both in developed markets and developing, crowdfunding is a complement or alternative to the classical banking system. Still, even in the largest markets, it is only a fraction of the financial market, although the observed trend is a fast growth of the sector. For example, the Chinese market is estimated by the CCAF at 215 billion (a decrease from 358 billion in 2017, due to the introduction of detailed regulations on this market), which is negligible with Chinese banks' assets - only ISCB has assets of 4.3 trillion (Caplen 2020). Nevertheless, even if compared with banks, it is not a big amount. It needs to be remembered crowdfunding often is directed to a different group of users, filling the gap on the market.

The next largest is the market of the United States with 61 billion and the United Kingdom-10 billion. Countries with a crowd sharing market of more than 1 billion are also the Netherlands, Indonesia, Germany, Australia, and Japan. There are 26 countries with a market between more than 100 million and 1 billion, and there are both highly developed countries such as France, Canada, South Korea, Finland, 
Sweden, and developing countries as Georgia, Armenia, Peru in this category. Furthermore, there are 38 countries in the USD 10-100 million category (Ziegler and Shneor 2020). The dominant form of crowdfunding is loans, while capital entries and other forms have a smaller share.

Of significance is that in many countries, there was a dynamic market growth in 2018, for which the latest data is available. In contrast, there are several countries where a notable reduction in the value of crowdfunding at that time has been. For example, in China, the decrease was from 358 billion in 2017 to 215 billion in 2018, as well as in South Korea from 1130 to 753 billion USD. At the same time, the market in Canada or New Zealand was stabilised $( \pm 10 \%)$. In most countries, the market growth between 2017 and 2018 was several dozen per cent. There were also countries where the market grew several times, e.g. the Netherlands (8x), Peru (5.4×), Argentina (4.3×), Japan $(3 \times)$, and about twice: Israel $(2.5 \times)$, Spain $(2.3 \times)$, Poland $(2.1 \times)$, Germany $(1.9 \times)$. All sources report the rapid growth of this market. Valuates Reports (Valuates Reports 2019b) expects the Compound Average Rate of Growth (CAGR) will arise $16 \%$ by 2025 , parallel it indicates the global Crowdfunding market size is projected to reach USD 23,200 Million by 2026, from USD 12,390 Million in 2019, at a CAGR of $11.2 \%$ during the forecast period 2021-2026 (Valuates Reports 2019a). Historical data collected by CCAF validate that growth rate. The Cambridge Centre for Alternative Finance identified 2322 companies globally in the research carried out in 2019, of which 1227 firms contributed to the study.

Statista estimates that transaction value is expected to show an annual growth rate (CAGR 2021-2025) of 3.33\% resulting in a projected total amount of US\$1,201.1 m by 2025 (Statista 2021, although such a low increase does not seem much credible. Looking regionally, Europe (including the UK) grew 52\% in 2018, Asia Pacific (excluding China) 69\%, Americas 44\%, the Middle East 131\%, and Africa 102\%. Against this background, China stands out significantly (-39.8\%), which is related to the introduction of new legal regulations related to crowdfunding loans (Ziegler and Shneor 2020). 
Importantly, crowdfunding is widespread. The countries where that phenomenon exceeded USD 1 million per year. In most African countries, crowdfunding amounts are very small—for the entire continent, crowdfunding in 2018 was only \$ 208 million, with only three countries accounting for half of the market: Zambia (40.7 million), Kenya (35 million), and South Africa (27.4 million USD) and the entire continent accounts for $>1 \%$ of the global crowdfunding market (Ziegler and Shneor 2020).

\section{Impact of the COVID-19 Pandemic}

The COVID-19 pandemic presented unprecedented health, economic, political, and social situation. It challenged a large number of assumptions in all domains of our life. Thus, the question we ask regarding crowdsourcing is how crowdfunding adopted the challenges created by COVID-19? To provide an initial answer to this question on Google Scholar, we performed a general literature search of papers that researched 'crowdfunding' and 'COVID-19' and published in 2020 or 2021. We download the papers and read the abstracts to identify the papers that fit our criteria. In the next paragraphs, we demonstrate how crowdsourcing was impacted by COVID-19.

As the awareness of the impact of COVID-19 increased, there was a rapid increase in the number of active campaigns (Rajwa et al. 2020). The goal was, as the economic impacts multiplied, to use web-based crowdfunding to defray these costs (Saleh et al. 2021). In the beginning, in different parts of the world, the focus was on different needs. The USA was more focused on the economic relief issues, while the nonUSA campaigns were more focused on the health workers or medical supplies, for example, in Italy (Rajwa et al. 2020). In the USA, from all the fundraising campaigns created between 1 January and 10 May 2020, 22.2\% were identified as COVID-19-related. Through COVID19 related campaigns, around the US $\$ 237$ million were collectively raised by 10 May 2020 (Saleh et al. 2021).

What we can notice is that the emergence that COVID-19 imposed has triggered organisations that have not relied on crowdfunding to 
quickly adapt and launch crowdfunding campaigns. For example, the World Health Organisation (WHO) launched the COVID-19 Solidarity Response Fund and asked individuals and organisations to donate funds in support of their COVID-19 pandemic-related work. The result is that '10 days after its 13 March launch, it had raised US\$71 million from 170000 individuals and organisations, including Facebook, Google, and FIFA' (Usher 2020, p. 1024). The crowdfunding approach enabled the WHO to quickly respond and provide different revenue stream when their traditional donors failed to fund the response to this outbreak at the international level (Usher 2020). Another example is non-profit advocacy coalitions in Belgium that launched crowdfunding platform to secure funds for 'complementary material services and aid that was not provided in the regular food packages distributed by food banks and social groceries' (Raeymaeckers and Van Puyvelde 2021, p. 9). This response to immediate needs is also present in the research of Ahsen et al. (2020) that identified that the new crowdfunding campaigns responded to the immediate needs around digital learning infrastructure necessary for online education of pupils.

Based on the above, we can say that during the pandemic, the crowdsourcing platforms assisted in augmenting the traditional relief efforts. However, the flexibility of the crowdfunding platforms and the ability to provide space for the creation of campaigns for emergent needs can also serve as an indicator of several important issues in crises. First, in a time of public health emergencies, it can provide which communities are affected and second, a unique insight into the needs of those affected communities (Saleh et al. 2021). In this way, it can provide information to the governmental institutions where the available funds can be directed. Thus, the new role of crowdfunding platforms is to provide signals where assistance is most needed during emergency situations.

However, during the pandemic, it has been identified that crowdfunding campaigns were organised for dietary supplements and immune system boosters that purported COVID-19 treatments that are not validated. This could bring confusion with the effective preventative approaches. Thus, there is a need for crowdfunding platforms to take a more proactive role in restricting campaigns that are based on misinformation about COVID-19 (Snyder et al. 2021). 
Finally, it is worth to be noted that as the COVID-19 pandemic persisted and progressed, the number of COVID-19 crowdfunding campaigns declined. In the USA, tenfold across all states (Saleh et al. 2021). However, 'COVID-19-related campaigns raised more money, had a long narrative description, and were more likely to be shared on Facebook than other campaigns in the study period' (Saleh et al. 2021). This decrease is due to rather successful campaigns that need to be explored further in order for a valid answer to be provided.

\section{Summary}

There has been noticed the disruption of the role, structure, and competitive environment for financial institutions, the markets, and societies in which they operated. It offers a variety of new tools and services to customers to pursue to enlarge the sharing economy. That is because peer-to-peer financial services companies create new partnerships with the FinTech sector ( $\mathrm{PwC}$ 2016).

Probably the most interesting market situation in crowdfunding is in Europe. On the one hand, we have intensive growth, in some European countries reaching several hundred \% year-on-year. On the other hand, uncertainty related to undefined obstacles as a result of Brexit. The total alternative finance market volume in Europe (including the UK) reached $\$ 18$ billion in 2018. The average growth rate between 2013 and 2018 was 69\%. The UK's exit from the EEA will disconnect Europe's largest crowdfunding market worth over 10 billion from the rest of the European Economic Area. The UK accounts for more than half of the European market. That is due to both the UK's large domestic market and the fact that UK crowdfunding platforms have done well in the European market. In Crowdsourcing Week's 'Top 15 Crowdfunding Platforms in Europe' ranking, British platforms take first and second position, and the UK is only one country with three platforms in the ranking (Priti 2020). Crowdfunding in Europe has attained a significant level of growth, adoption, and maturity in recent years.

The development of the crowdfunding market in Europe is of interest to the European Commission. The first studies on crowdfunding date 
back to 2011 and culminated in Communication from the Commission to The European Parliament, The Council, The European Economic and Social Committee, and The Committee Of The Regions Unleashing the Potential of Crowdfunding in the European Union (European Commission 2014) clarifying the directions in which the regulation of legal crowdfunding framework across Europe head to.

Most crowdfunding markets in Europe have recorded significant growth rates of several tens of $\%$ per year in recent years. It is likely that such a pace will not be maintained. Three factors affecting that market are important in 2020 and 2021. The first is the COVID-19 epidemic, which is having a slowing effect on entire sectors of the economy, as confirmed by Eurostat statistics, such as falling household savings rates in 2020, rising unemployment (by one percentage point during the first six months of the pandemic), or a fall in GDP estimated at more than seven percentage points (European Commission 2020b). In a survey carried out by the European Crowdfunding Network, crowdfunding platform managers are most afraid of declines in the lending market. When looking at the perceived impact on incoming capital flows, there is a high negative impact found, especially on lending, with most respondents indicating a high decline in capital inflows of more than $50 \%$. Equity platforms are also perceiving a high negative impact (European Crowdfunding Network 2020).

The second factor that could negatively impact the crowdfunding market is Brexit, which will remove UK-based crowdfunding platforms from outside the EEA market. Even if appropriate agreements are in place to allow such activity to continue to operate directly on the continent, trust in these platforms as coming from outside the single market is expected to decline.

A third factor that may, however, stimulate the market is the enactment of Regulation (EU) 2020/1503, which may significantly accelerate the development of the crowdfunding market, once it comes into force (Regulation (EU) 2020/1503 of the European Parliament and of the Council of 7 October 2020 on European Crowdfunding Service Providers for Business, and Amending Regulation (EU) 2017/1129 and Directive (EU) 2019/1937 (Text with EEA Relevance) 2020). 


\section{References}

Ahsen, Mehmet, Aravinda Garimella, Ramanath Subramanyam, and Anqi Angie Wu. 2020. 'Keeping Kids Learning: Online Crowdfunding Communities Respond to the COVID-19 Pandemic.' Illinois Experts, Working Paper, Available at SSRN 3779438. Accessed December 15, 2020. https://doi.org/ 10.2139/ssrn.3779438.

Allison, Thomas H., Aaron F. McKenny, and Jeremy C. Short. 2013. 'The Effect of Entrepreneurial Rhetoric on Microlending Investment: An Examination of the Warm-Glow Effect.' Journal of Business Venturing 28 (6): 690-707. https://doi.org/10.1016/j.jbusvent.2013.01.003.

Andreoni, James. 1990. 'Impure Altruism and Donations to Public Goods: A Theory of Warm-Glow Giving.' The Economic Journal 100 (401): 464-477. https://doi.org/10.2307/2234133.

Belleflamme, Paul, Thomas Lambert, and Armin Schwienbacher. 2014. 'Crowdfunding: Tapping the Right Crowd'. Journal of Business Venturing 29 (5): 585-609. https://doi.org/10.1016/j.jbusvent.2013.07.003.

Belleflamme, Paul, Nessrine Omrani, and Martin Peitz. 2015. 'The Economics of Crowdfunding Platforms.' Information Economics and Policy 33 (4): 1128. https://doi.org/10.1016/j.infoecopol.2015.08.003.

Berns, John P, Maria Figueroa-Armijos, Serge P da Motta Veiga, and Timothy C Dunne. 2020. 'Dynamics of Lending-Based Prosocial Crowdfunding: Using a Social Responsibility Lens.' Journal of Business Ethics 161 (1): 169-185. https://doi.org/10.1007/s10551-018-3932-0.

Bocken, Nancy M.P. 2015. 'Sustainable Venture Capital - Catalyst for Sustainable Start-up Success?' Journal of Cleaner Production 108 (December): 647-658. https://doi.org/10.1016/j.jclepro.2015.05.079.

Butticè, Vincenzo, Chiara Franzoni, Cristina Rossi-Lamastra, and Paola Rovelli. 2018. 'The Road to Crowdfunding Success: A Review of Extant Literature.' In Creating and Capturing Value through Crowdsourcing, edited by Christopher L. Tucci, Allan Afuah, and Gianluigi Viscusi, 97-115. New York, NY: Oxford University Press. https://doi.org/10.1093/oso/9780198816225.003. 0005 .

Cai, Cynthia Weiyi. 2018. 'Disruption of Financial Intermediation by FinTech: A Review on Crowdfunding and Blockchain.' Accounting \& Finance 58 (4): 965-92.

Caplen, Brian. 2020. 'Top 1000 World Banks 2020 China Press Release.' The Banker, 2020. Accessed December 10, 2020. https://www.thebanker.com/ 
Top-1000-World-Banks/Top-1000-World-Banks-2020-China-Press-ReleaseEnglish.

Elkington, John Brett. 1999. 'Cannibals with Forks: The Triple Bottom Line of Sustainability.' New Society Publishers. Oxford: Capstone Publishing Ltd. https://doi.org/10.1002/tqem.3310080106.

Ensley, Michael D., Allison W. Pearson, and Allen C. Amason. 2002. 'Understanding the Dynamics of New Venture Top Management Teams: Cohesion, Conflict, and New Venture Performance.' Journal of Business Venturing 17 (4): 365-386.

European Commission. 2014. 'Communication from the Commission to The European Parliament, The Council, The European Economic And Social Committee And The Committee Of The Regions Unleashing the Potential of Crowdfunding in the European Union.' Brussels: European Commission. Accessed December 5, 2020. https://eur-lex.europa.eu/legal-content/ en/TXT/?uri=CELEX:52014DC0172.

European Commission. 2020a. 'Internal Market, Industry, Entrepreneurship and SMEs. Crowdfunding.' Accessed November 15, 2020. https://ec.europa.eu/ growth/access-to-finance/funding-policies/crowdfunding/.

European Commission. 2020b. 'Summer 2020 Economic Forecast: An Even Deeper Recession with Wider Divergences.' Accessed April 20, 2021. https:// ec.europa.eu/commission/presscorner/detail/\%0Aen/ip_20_1269.

European Crowdfunding Network. 2020. 'The Impact of COVID-19 on the European Automotive Market.' Brussels: European Crowdfunding Network AISBL. Accessed March 15, 2021. https://eurocrowd.org/wp-content/blogs. dir/sites/85/2020/04/ECN_COVID19_Survey_20200414.pdf.

Grant, Robert. M. 1991. 'The Resource-Based Theory of Competitive Advantage: Implications for Strategy Formulation.' California Management Review 33 (3): 114-135.

Guan, Lei. 2016. 'A Short Literature Review on Reward-Based Crowdfunding.' Paper Presented at the 2016 13th International Conference on Service Systems and Service Management (ICSSSM), 1-4. https://doi.org/10.1109/ICSSSM. 2016.7538636.

Herrero, Ángel, Blanca Hernández-Ortega, and Héctor San Martín. 2020. 'Potential Funders' Motivations in Reward-Based Crowdfunding. The Influence of Project Attachment and Business Viability.' Computers in Human Behavior 106: 106240. https://doi.org/10.1016/j.chb.2019.106240.

Kirby, Eleanor, and Shane Worner. 2014. 'Crowdfunding : An Infant Industry Growing Fast'. International Organization of Securities Commissions, 1-62. http://www.iosco.org/library/pubdocs/pdf/IOSCOPD459.pdf. 
Lagazio, Corrado, and Francesca Querci. 2018. 'Exploring the Multi-Sided Nature of Crowdfunding Campaign Success.' Journal of Business Research 90: 318-324. https://doi.org/10.1016/j.jbusres.2018.05.031.

Löher, Jonas. 2017. 'The Interaction of Equity Crowdfunding Platforms and Ventures: An Analysis of the Preselection Process.' Venture Capital 19 (1-2): 51-74. https://doi.org/10.1080/13691066.2016.1252510.

Martínez-Climent, Carla, Ana Zorio-Grima, and Domingo Ribeiro-Soriano. 2018. 'Financial Return Crowdfunding: Literature Review and Bibliometric Analysis.' International Entrepreneurship and Management Journal 14 (3): 527-553.

Mochkabadi, Kazem, and Christine K Volkmann. 2020. 'Equity Crowdfunding: A Systematic Review of the Literature.' Small Business Economics 54 (1): 75-118.

Morduch, Jonathan. 1999. 'The Microfinance Promise.' Journal of Economic Literature 37 (4): 1569-1614. https://doi.org/10.1257/jel.37.4.1569.

Pierrakis, Yannis, and Liam Collins. 2013. Banking on Each Other: Peerto-Peer Lending to Business: Evidence from Funding Circle. London: Nesta Operating Company. https://www.nesta.org.uk/documents/71/ban king_on_each_other.pdf.

Poetz, Marion K., and Martin Schreier. 2012. 'The Value of Crowdsourcing: Can Users Really Compete with Professionals in Generating New Product Ideas?' The Journal of Product Innovation Management 29 (2): 245-256.

Priti, Ambani. 2020. 'Top 15 Crowdfunding Platforms in Europe.' Crowd Sourcing Week. Accessed March 15, 2021. https://crowdsourcingweek.com/ blog/top-15-crowdfunding-platforms-in-europe/.

PwC. 2016. 'Financial Services Technology 2020 and Beyond: Embracing Disruption.' New York. https://www.pwc.com/gx/en/financial-services/ass ets/pdf/technology2020-and-beyond.pdf.

Raeymaeckers, Peter, and Stijn Van Puyvelde. 2021. 'Non-profit Advocacy Coalitions in Times of COVID-19: Brokerage, Crowdfunding, and Advocacy Roles.' Non-profit and Voluntary Sector Quarterly (forthcoming). https:// doi.org/10.1177/0899764021991675.

Rajwa, Pawel, Philip Hopen, Lin Mu, Andrzej Paradysz, Jakub Wojnarowicz, Cary P Gross, and Michael S Leapman. 2020. 'Online Crowdfunding Response to Coronavirus Disease 2019.' Journal of General Internal Medicine 35(8): 2482-2484. https://doi.org/10.1007/s11606-020-05896-x.

Regulation (EU) 2020/1503 of the European Parliament and of the Council of 7 October 2020 on European Crowdfunding Service Providers for Business, and Amending Regulation (EU) 2017/1129 and Directive (EU) 2019/1937 
(Text with EEA Relevance). 2020. Brussels: European Parliament and the Council. Accessed March 20, 2021 https://eur-lex.europa.eu/legal-content/ EN/TXT/?uri=CELEX:32020R1503.

Renwick, Matthew J., and Elias Mossialos. 2017. 'Crowdfunding Our Health: Economic Risks and Benefits.' Social Science and Medicine 191: 48-56. https://doi.org/10.1016/j.socscimed.2017.08.035.

Rossi, Alice, and Silvio Vismara. 2018. 'What Do Crowdfunding Platforms Do? A Comparison between Investment-Based Platforms in Europe.' Eurasian Business Review 8 (1): 93-118. https://doi.org/10.1007/s40821017-0092-6.

Ruef, Martin, Howard E. Aldrich, and Nancy M. Carter. 2003. 'The Structure of Founding Teams: Homophily, Strong Ties, and Isolation among US Entrepreneurs.' American Sociological Review 68 (2): 195-222.

Saleh, Sameh Nagui, Christoph U Lehmann, and Richard J Medford. 2021. 'Early Crowdfunding Response to the COVID-19 Pandemic: CrossSectional Study.' Journal of Medical Internet Research 23 (2): e25429.

Salido-Andres, Noelia, Marta Rey-Garcia, Luis Ignacio Alvarez-Gonzalez, and Rodolfo Vazquez-Casielles. 2021. 'Mapping the Field of Donation-Based Crowdfunding for Charitable Causes: Systematic Review and Conceptual Framework.' VOLUNTAS: International Journal of Voluntary and Nonprofit Organizations 32 (2): 288-302. https://doi.org/10.1007/s11266-020-002 13-w.

Schwienbacher, Armin, and Benjamin Larralde. 2012. 'Crowdfunding of Small Entrepreneurial Ventures.' In The Oxford Handbook of Entrepreneurial Finance, edited by Douglas Cumming, 23. Oxford: Oxford University Press. https://doi.org/10.1093/oxfordhb/9780195391244.013.0013.

Short, Jeremy C, David J Ketchen Jr, Aaron F McKenny, Thomas H Allison, and R Duane Ireland. 2017. 'Research on Crowdfunding: Reviewing the (Very Recent) Past and Celebrating the Present.' Entrepreneurship Theory and Practice 41 (2): 149-160.

Snyder, Jeremy, Marco Zenone, and Timothy Caulfield. 2021. 'Crowdfunding Campaigns and COVID-19 Misinformation.' American Journal of Public Health 111 (4): 739-742.

Statista. 2021. 'Crowdfunding.' Accessed March 8, 2021. https://www.statista. $\mathrm{com} /$ outlook/dmo/fintech/alternative-financing/crowdfunding/worldwide.

Usher, Ann Danaiya. 2020. 'WHO Launches Crowdfund for COVID-19 Response.' The Lancet 395 (10229): 1024. https://doi.org/10.1016/S01406736(20)30719-4. 
Valuates Reports. 2019a. 'Global Crowdfunding Market Size, Status and Forecast 2021-2027.' tps://reports.valuates.com/market-reports/QYRE-Auto$1598 /$ global-crowdfunding.

Valuates Reports. 2019b. 'The Global Crowdfunding Market Was Valued at 10.2 Billion US\$ in 2018 and Is Expected to Reach 28.8 Billion US\$ with a CAGR of 16\% by 2025 - Valuates Reports.' Accessed April 8, 2021. https://www. prnewswire.com/in/news-releases/the-global-crowdfunding-market-was-val ued-at-10-2-billion-us-in-2018-and-is-expected-to-reach-28-8-billion-uswith-a-cagr-of-16-by-2025-valuates-reports-888819175.html.

Wang, Tao, Yalan Li, Minghui Kang, and Haichao Zheng. 2019. 'Exploring Individuals' Behavioral Intentions toward Donation Crowdfunding: Evidence from China.' Industrial Management \& Data Systems 119 (7): 1515-1534. /https://doi.org/10.1108/IMDS-10-2018-0451.

Zhang, Yali, Chrissie Diane Tan, Jun Sun, and Zhaojun Yang. 2020. 'Why Do People Patronise Donation-Based Crowdfunding Platforms? An Activity Perspective of Critical Success Factors.' Computers in Human Behavior 112 (11): 1-9. https://doi.org/10.1016/j.chb.2020.106470.

Zhao, Qun, Chun Der Chen, Jin Long Wang, and Pin Chung Chen. 2017. 'Determinants of Backers' Funding Intention in Crowdfunding: Social Exchange Theory and Regulatory Focus.' Telematics and Informatics 34 (1): 370-84. https://doi.org/10.1016/j.tele.2016.06.006.

Ziegler, Tania, and Rotem Shneor, eds. 2020. 'The Global Alternative Finance Market Benchmarking Report.' Cambridge: University of Cambridge. Accessed March 30, 2021. https://www.jbs.cam.ac.uk/faculty-research/cen tres/alternative-finance/publications/the-global-alternative-finance-marketbenchmarking-report/.

\section{Suggested Readings}

Andreoni, Valeria. 2019. 'Sharing Economy: Risks and Opportunities in a Framework of SDGs.' In Sustainable Cities and Communities, edited by Walter Leal Filho, Anabela Marisa Azul, Luciana Brandli, Pinar Gökcin Özuyar, and Tony Wall, 1-9. Cham: Springer International Publishing. https://doi.org/10.1007/978-3-319-71061-7_60-1.

Munger, Michael C. 2018. Tomorrow 3.0: Transaction Costs and the Sharing Economy. New York: Cambridge University Press. 
Parker, Geoffrey, Marshall Van Alstyne, and Sangeet Paul Choudary. 2017. Platform Revolution: How Networked Markets Are Transforming the Economy and How to Make Them Work for You. First published as a Norton paperback. New York London: W. W. Norton \& Company.

\section{Relevant Websites}

Internal Market, Industry, Entrepreneurship and SMEs: https://ec.europa.eu/ growth/single-market/services/collaborative-economy_en.

What do we share in a sharing economy?: https://www.un.org/development/ desa/undesavoice/more-from-undesa/2020/03/48735.html.

Open Access This chapter is licensed under the terms of the Creative Commons Attribution 4.0 International License (http://creativecommons.org/ licenses/by/4.0/), which permits use, sharing, adaptation, distribution and reproduction in any medium or format, as long as you give appropriate credit to the original author(s) and the source, provide a link to the Creative Commons license and indicate if changes were made.

The images or other third party material in this chapter are included in the chapter's Creative Commons license, unless indicated otherwise in a credit line to the material. If material is not included in the chapter's Creative Commons license and your intended use is not permitted by statutory regulation or exceeds the permitted use, you will need to obtain permission directly from the copyright holder. 